\title{
АНАЛІЗ МЕТОДІВ ПРОГНОЗУВАННЯ ТЕХНІЧНОГО СТАНУ ЗАСОБІВ ВОДНОГО ТРАНСПОРТУ
}

Відомо, щзо рівень безаварійного судноводіння, показники якості та ефективності перевезень пасажирів та вантажів продовжують покрамуватися. Особлива увага приділяється саме заходам забезпечення заданого рівня надійності технічних засобів. Значна роль в иььому напрямку - рішення завдання прогнозування технічного стану засобів водного транспорту. Це ще більш підкреслює актуальність наукових досліджень з метою підвищення ефективності технічної експлуатащії морських та річних транспортних засовів за рахунок використання інформачії про прогноз їх технічного стану.

На теперішній час для забезпечення гарантованого рівня достовірності прогнозування технічного стану засобів водного транспорту активне використовують прогресивні апаратні так програмні рішення. Аналіз закордонного та вітчизняного досвіду розробки та впровадження систем прогнозування технічного стану як комплектуючих підсистем, так $\ddot{i}$ засобів водного транспорту в цілому свідчить про можливість значного підвищення їх ефективності за рахунок розвитку математичного та алгоритмічного забезпечення. Найбільш актуальним в изьому напрямку є використання моделей та методів штучного інтелекту, а саме, так званих м'яких обчислень.

Ключові слова: модель, метод, прогнозування, технічний стан, засоби водного транспорту, методи штучного інтелекту, м'які обчислення.

Постановка проблеми у загальному вигляді та ї̈ зв'язок із важлливми науковими чи практичними завданнями. В сучасних умовах не викликає сумніву те, що саме водний транспорт, як інфраструктурна галузь, має розвиватися швидкими темпами. На думку експертів у 2020-2022 роках, очікується збільшення обсягу перевезення вантажів морськими та річними судами до 2500 млн. тон; переробка вантажів у державних торговельних портах також збільшиться та становитиме близько 240 млн. тон; обсяги пасажирських перевезень становитимуть більш 10900 млн. пасажирів.

Дослідження, яке виконане в межах даної дисертації показує, що рівень безаварійного судноводіння, показники якості та ефективності перевезень пасажирів та вантажів продовжують покращуватися. Особлива увага приділяється саме заходам забезпечення заданого рівня надійності технічних засобів. Значна роль в цьому напрямку - рішення завдання прогнозування технічного стану засобів водного транспорту. Це ще більш підкреслює актуальність наукових досліджень з метою підвищення ефективності технічної експлуатації морських та річних транспортних засовів за рахунок використання інформації про прогноз їх технічного стану.

Аналіз останніх досліджень і публікацій, в яких започатковано розв'язання даної проблеми. Технічний стан ЗВТ $є$ суттєвим фактором забезпечення безаварійного судноводіння. Аналіз офіційних статистичних даних стосовно аварійності на водному транспорті 2016-2019 р.р наведено на рис.1.

Загальна кількість аварійних подій, що сталися протягом 1-го півріччя 2019 року, у порівнянні з 2018 роком збільшилась на 10 аварійних подій (200\%), кількість загиблих та зниклих - збільшилась на 6 осіб (600 \%). Кількість травмованих осіб збільшилась на 4 осіб $(80 \%) . »$. 


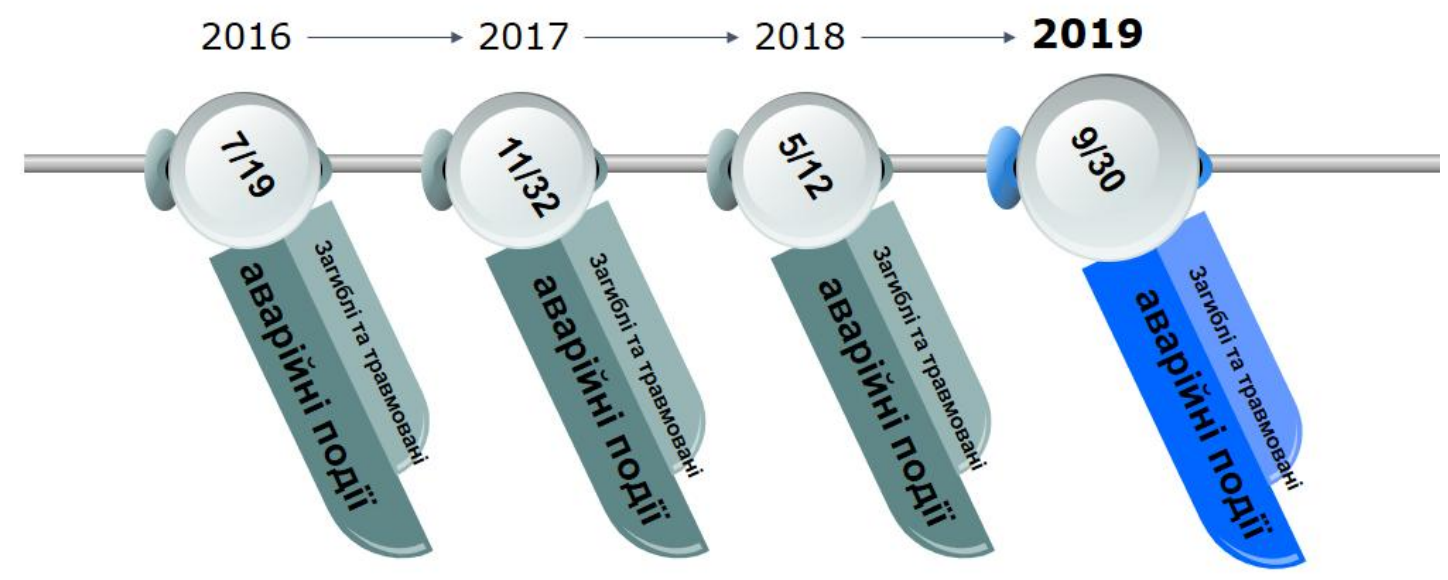

Рис.1. Аналіз аварійності на водному транспорті 2016-2019 р.p.

Актуальність досліджень підкреслює ї наступна офіційна інформація.

За результатами проведених розслідувань аварійних подій, що трапилися за період січень-червень 2019 року, встановлено, що причинами їх виникнення були наступні (див. рис. 2.).

Матеріали НДР за темою: «Підвищення ефективності операторської діяльності в суднових ергатичних системах на морському транспорті», (Одеська Національна морська академія) (рис. 3) також підтверджують, що значна кількість аварійних ситуацій обумовлена так званим технічними причинами.

Таким чином, аналіз стану безпеки руху засобів морського та водного транспорту України дозволяє зробити висновок про те, що саме «технічні причини» $є$ найбільш значною причиною аварійності на морському та річному флоті за останні роки.

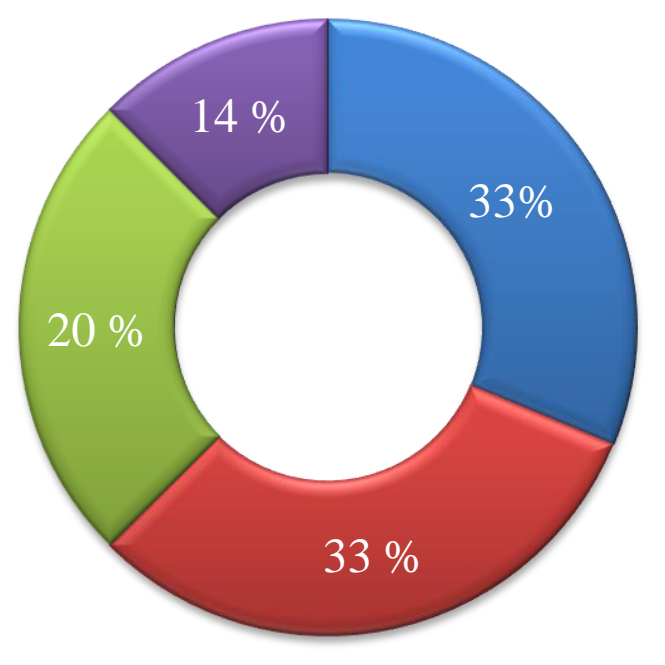

๑ Навігаційні

$\square$ Технічні

$\square$ Організаційні

П Пзихофізіолог ічні

Рис. 2 .Статистика аварійних подій за причинами виникнення у першому півріччі 2019 року 


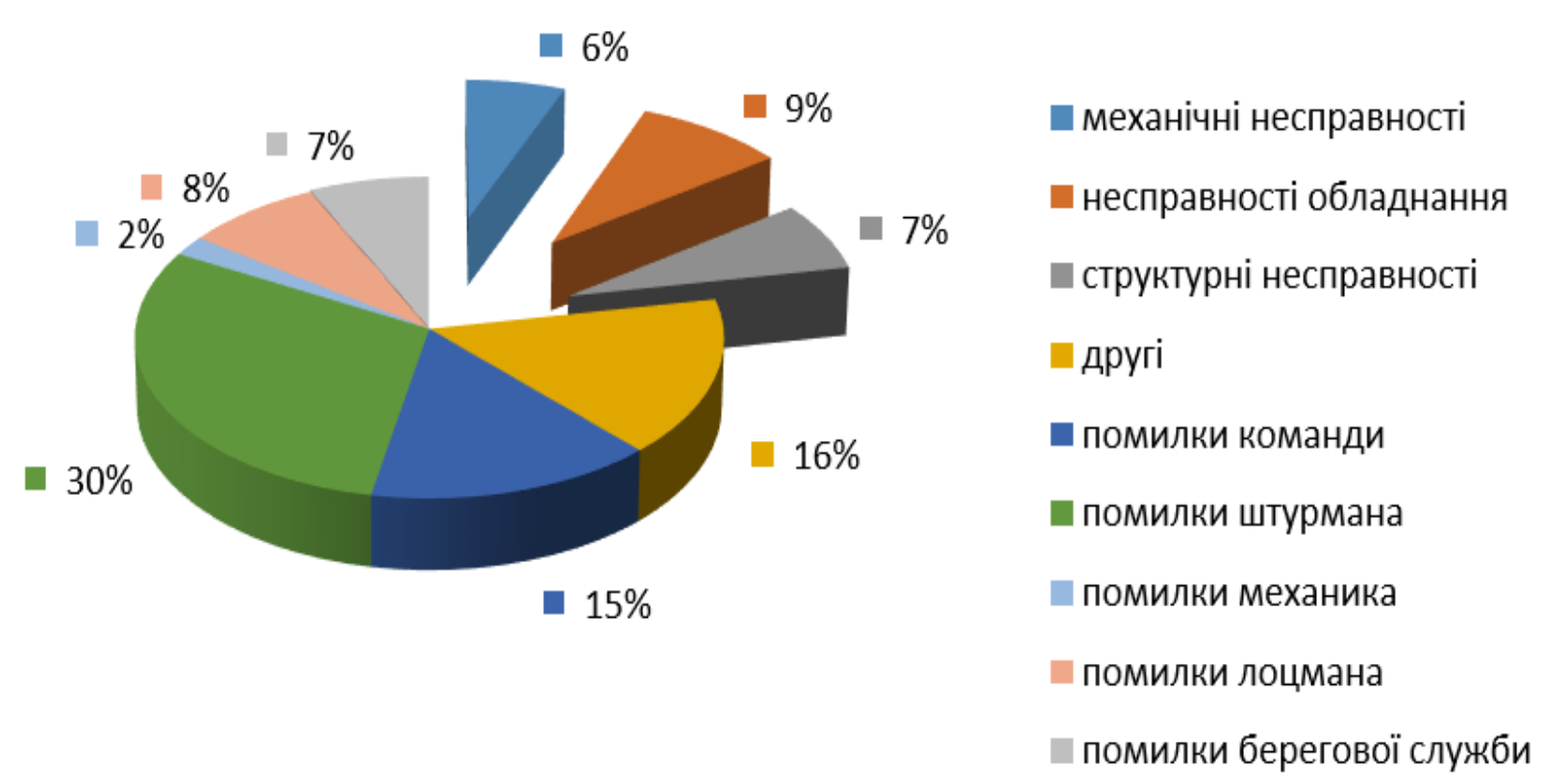

Рис.3. Причини аварійних ситуацій на морському транспорті

Тому дослідження, які спрямовані на «...розроблення методів підвищення ефективності ... прогнозування технічного стану засобів транспорту, що забезпечують високу ефективність їх використання та надійність роботи» $є$ актуальними та важливими для безаварійного судноводіння [1].

Визначення технічного стану судна $є$ обов'язковою рисою його експлуатації, яке виконуються згідно ДСТУ 2389-94 «Технічне діагностування та контроль технічного стану. Терміни та визначення» [1] та інших керівних документів. Наприклад, «Інструкція 3 проведення технічного нагляду за суднами рибної промисловості України, що не підлягають нагляду класифікаційного товариства» [1,2] вимагає: «4.1. Технічний стан судна визначається за результатами огляду його корпусу, надбудови, пристроїв, обладнання, механічної установки, електрообладнання та перевірки протипожежного захисту».

Для класифікації придатності судна до плавання існують три оцінки технічного стану: «придатне», «обмежено придатне» та «заборонене до експлуатації». Судна, які «обмежено придатні», можуть допущені до плавання за умови обмеження: району плавання та віддалення від берега; допустимої потужності двигуна; вантажопідйомності $[3,4]$.

Формулювання цілей статті (постановка завдання). Тому ціллю даної статті $\epsilon$ аналіз методів прогнозування технічного стану засобів водного транспорту та постановка наукового завдання з метою покращення достовірності прогнозування технічного стану

Визначення напрямків підвищення достовірності прогнозування технічного стану суден. Дослідження показали те, що сучасні засоби діагностики та прогнозування технічного стану ЗВТ базуються на використанні ознак та характеристик різноманітних фізичних явищ, реалізацію складних технологій збору, обробки, зберігання, передавання та представлення інформації.

Тому достовірна оцінка технічного стану ЗВТ як на стадії експлуатації, так ї в загалі передбачає використання відповідних діагностичних апаратних та програмних засобів, складовими частинами якого є технологічне, апаратурне, математичне, алгоритмічне та програмне забезпечення.

У зв'язку з цим основні напрямки підвищення достовірності прогнозування технічного стану суден спрямовані на розвиток математичних методів виділення і розпізнавання діагностичної інформації, створення ефективних вимірювальних комплексних систем збору, обробки та 
представлення інформації, пошук діагностичних ознак деградації технічного стану, синтез алгоритмів прогнозування, орієнтованих на застосування тих чи інших методів і засобів прогнозування [4,5].

Слід зазначити, що розширене впровадження засобів прогнозування технічного стану ЗВТ, з одного боку, стимулюється неухильно зростаючими вимогами до надійності і безпеки експлуатації суден і кораблів, але з іншого боку, пов'язано з необхідністю вирішення цілого ряду проблем, пов'язаних з недостатньою вивченістю алгоритмів експлуатаційних відмов та пошкоджень найбільш навантажених вузлів і деталей, відсутністю необхідної кількості статистичних даних про характеристики експлуатаційних відмов, складністю отримання адекватних але повних та достовірних моделей оцінки та прогнозування технічного стану комплектуючих 3ВТ та ін. [5,7].

3 іншого боку на ринку представлена найширша номенклатура діагностичних приладів i систем, (як вітчизняних, так і імпортних) що розрізняються особливостями методичного, математичного, алгоритмічного, програмного та апаратного забезпечення, та мають різні принципи дії, функціональні можливості, метрологічні характеристики, області застосування, масогабаритні параметри, елементну базу, співвідношення ціни та ін. [7,8].

На думку експертів це призвело до того, що на зміну проблеми дефіциту діагностичних методик i приладів прийшла нова проблема - проблема вибору компонування діагностичного забезпечення, яке здатне забезпечити потрібний рівень достовірності прогнозування та діагностування. Рішення цієї проблеми вимагає, як правило, проведення комплексу теоретичних i експериментальних досліджень, спрямованих на аналіз специфічних умов експлуатації ЗВТ, конструктивних особливостей обладнання, аналіз умов навантаження і характерних експлуатаційних пошкоджень найбільш відповідальних вузлів і деталей, визначення можливих діагностичних ознак, розробки діагностичних методів i приладів, здатних функціонувати в суднових умовах експлуатації [5-8].

Таким чином, головною тенденцією еволюції систем контролю та прогнозування технічного стану як суднового обладнання, так ї ЗВТ в цілому слід вважати перехід від екстенсивного розвитку систем централізованого контролю до якісної зміни їх функціональних можливостей за рахунок застосування спеціальних діагностичних методик, алгоритмів і апаратури, адаптованих до специфічних особливостей об'єктів діагностування.

Тут слід зауважити, що практична реалізація цього завдання за своєю складністю і багатоплановості не поступається завдання забезпечення високого рівня автоматизації суднових технічних засобів.

Варте звернути увагу на те, що сучасний високо достовірний процес прогнозування ТС безумовне пов'язаний саме 3 комп'ютерною обробкою інформації з застосуванням передових технологій. Тому цей напрям - широкий спектр питань штучного інтелекту (ШІ) [9].

Під штучним інтелектом розуміють комплексний науковий напрямок, метою якого $є$ створення і застосування програмно-апаратних засобів, що дозволяють моделювати процес людського мислення (окремі функції творчої діяльності) і забезпечувати діалог 3 комп’ютером мовою, природною для людини. ШІ - це метафорична назва нових інформаційних технологій обробки інформації, створених фахівцями різноманітних галузей науки і техніки (математиками, інженерами, психологами, лінгвістами, військовими вченими та ін.).

Основними напрямками застосування систем ШІ, з точки зору їхнього використання є: навчальні програми; логіко-лінгвістичні моделі; гібридні експертні системи; системи підтримки прийняття рішень (СППР); обробка зображень; розпізнавання образів (ситуацій).

Термін "м'які обчислення" (Soft Computing) був запроваджено в 1994 p. основоположником теорії нечітких множин Л.Заде (Zadeh, Lotfi A., «Fuzzy Logic, Neural Networks, and Soft Computing», Communications of the ACM, March 1994, Vol. 37 No. 3, pp 7784.). Традиційний термін "штучний інтелект" був розширений до термін "обчислювальний інтелект" , який пов'язують 3 концепцією м'яких обчислень і м'яких знань. На нашу думку, термін "м'які обчислення" в математичному та алгоритмічному сенсі базується на наступних 
моделях та методах: теорія можливостей; нечіткі множини, нечітка логика, нечітке управління і споріднені з ними формалізми для моделювання невизначеності; можливостеімовірнісні моделі та методи прийняття рішень; еволюційне моделювання та генетичні алгоритми; системи з хаотичною динамікою [9].

Таким чином, перспективні напрямки підвищення достовірності прогнозування ТС ЗВТ в алгоритмічному сенсі, безумовно базуються та так званих м’яких обчисленнях (рис.4).

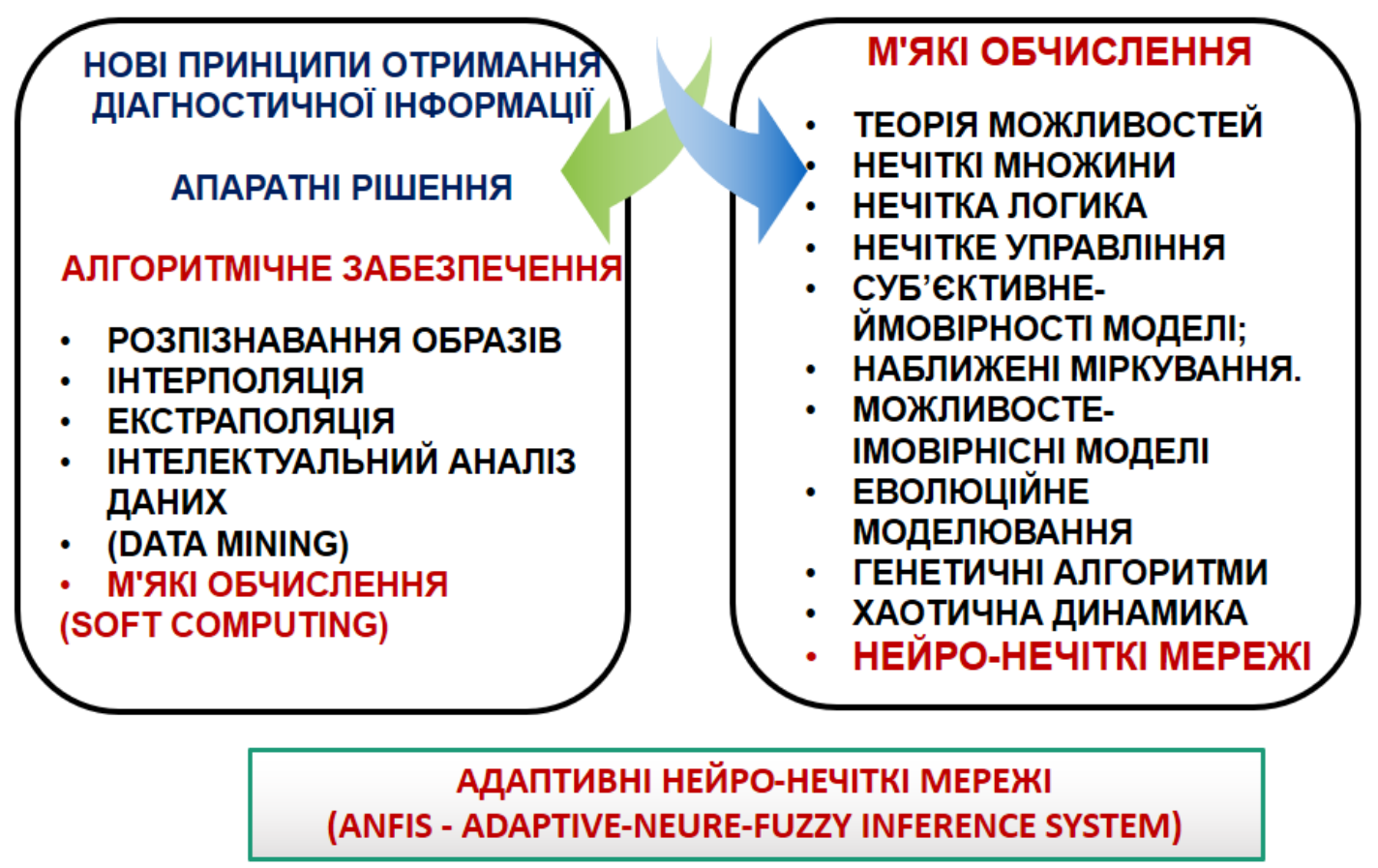

Рис.4. Напрямки підвищення достовірності прогнозування ТС 3ВТ

Створення ефективного інтелектуалізованого діагностичного забезпечення передбачає, перш за все проведення системного аналізу об'єктів діагностування та прогнозування 3 метою виділення і типізації характерних процесів деградації технічного стану найбільш навантажених і відповідальних вузлів і деталей, що лімітують безвідмовність і довговічність обладнання, визначення раціональної глибини діагностування, систематизації діагностичних завдань і подальшого аналізу і вибору методів і засобів діагностування, а також визначення вихідних передумов для дослідження і розробки принципово нових діагностичних методик.

\section{Постановка наукового завдання.}

Дослідження, яке виконане в межах науккової праці показує, що рівень безаварійного судноводіння, показники якості та ефективності перевезень пасажирів та вантажів продовжують покращуватися. Особлива увага приділяється саме заходам забезпечення заданого рівня надійності. Значна роль в цьому напрямку - рішення завдання прогнозування технічного стану засобів водного транспорту.

Незважаючи на стрімкий розвиток теорії штучного інтелекту взагалі, актуальним $\epsilon$ наукове завдання удосконалення існуючих та розробки нових моделей та методів прогнозування технічного стану засобів водного транспорту на основі м'яких обчислень, вирішенню цього завдання ї присвячена дана робота.

Дамо символьну формалізацію наукового завдання.

Потрібне визначити кортеж

$$
\langle\beta, T, X, G, M\rangle,
$$


де $\beta$ - лінгвістична змінна технічного стану 3ВТ;

$T$ - множина термів лінгвістичної змінної $\beta$;

$T=\{$ «придатне», «обмежено придатне», «заборонене до експлуатації»\},

$X$ - універсум (область значень лінгвістичної змінної технічного стану 3ВТ);

$G$ - синтаксична процедура, яка описує процес генерування з множені Т нових значень лінгвістичної змінної $\beta$;

$M$ - семантична процедура, яка визначає відповідність кожному новому значенню лінгвістичної змінної $\beta$ (яке отримане за допомогою $G$ ) елементам деякої нечіткої множені.

Структурне-логічна схема постановки наукового завдання наведено на рис.5.

\section{ПРОГНОЗУВАННЯ ТЕХНІЧНОГО СТАНУ}

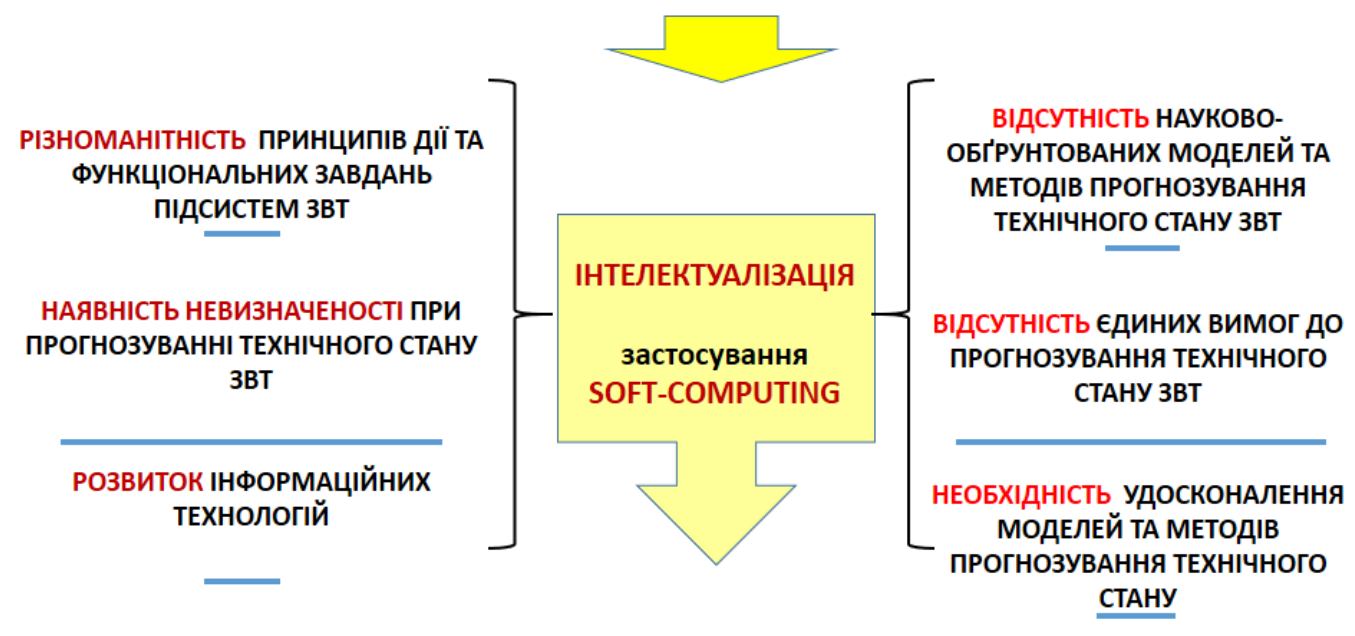

НАУКОВЕ ЗАВДАННЯ: удосконалення існуючих та розробки нових моделей та методів прогнозування технічного стану засобів водного транспорту на основі м'яких обчислень.

Рис.5. Структурне-логічна схема постановки наукового завдання

Таким чином, надана формальна постановка актуального нового наукового завдання удосконалення існуючих та розробки нових моделей та методів прогнозування технічного стану засобів водного транспорту на основі м'яких обчислень, що безпосередньо впливає на підвищення достовірності прогнозу ТС за рахунок автоматизації та комп'ютеризації. Доцільно підкреслити, що данні моделі та методи реалізуються саме в математичному, алгоритмічному та програмному забезпечені бортової комп’ютерної системи, наприклад, в так званої інтегрованої мостікової системі (Integrated Bridge System) [10, 11].

\section{Висновки 3 даного дослідження і перспективи подальших досліджень у даному напрямку.}

1. На даний час водний транспорт України у цілому характеризується покращенням рівня безпеки судноводіння, показників якості та ефективності перевезень пасажирів та вантажів. Доведено те, що водний транспорт з метою сприяння швидкому економічному, соціальному та політичному розвитку країни має розвиватися випереджальними темпами. Очікується, що у 2020-2022 роках обсяги перевезення вантажів збільшиться в порівняні з 2010 роком на 40 \%, переробка вантажів у державних портах - на 45 \%, обсяги пасажирських перевезень - на $30 \%$.

2. На підставі результатів аналізу досвіду експлуатації та розвитку транспортної галузі України та провідних країн світу встановлено, що в сучасних умовах технічні фактори, які впливають на аварії водного транспорту складають до $30 \%$ від загальної кількості. А це 
безумовно, підкреслює необхідність забезпечення заданого рівня надійності ЗВТ.

3. На думку фахівців загальна проблема надійності засобів водного транспорту має достатню кількість складових, 3 яких завдання прогнозування технічного стану ЗВТ $\epsilon$ важливим на актуальним. В сучасних умовах існує багато напрямків вирішення цього завдання, але дослідження показали, що на даний час існує необхідність пошуку нових підходів, методів та моделей. Це пов'язано 3 тім що в більшості ситуацій відсутня статистична або будь-яка апріорна інформація про можливі зовнішні впливи та дестабілізуючи фактори. Забезпечення високого рівня достовірності прогнозу потребує ефективних підходів, з яких найбільш доцільним $є$ той, що заснований на штучному інтелекті.

4. Аналіз існуючих науково-обгрунтованих підходів підвищення ефективності складних технічних систем, до яких повною мірою відноситься й інтелектуальна транспортна система, дозволив зробити висновок про формування за останні роки нового пріоритетного підходу, пов'язаного із реалізацією принципів теорії штучного інтелекту - м'яких обчислень. Таким чином, загальне наукове завдання щодо розвитку моделей, методів, методик та алгоритмів прогнозу технічного стану ЗВТ на основі м'яких обчислень $є$ важливим та актуальним для науки та практики.

\section{ЛІТЕРАТУРА}

1. Публічний звіт Голови Державної служби України з безпеки на транспорті М. Ноняка за 2017 рік. Державна служба України з безпеки на транспорті : веб сайт. URL: http://dsbt.gov.ua/storinka/publichnyy-zvit-golovy-derzhavnoyi-sluzhby-ukrayiny-z-bezpekyna-transporti-myhayla-0 (дата звернення: 09.12.2018).

2. Абрамов О.В. Контроль и прогнозирование технического состояния систем ответственного назначения. Надежность и качество сложных систем. 2018. № 4 (24). C. $108-115$.

3. Михайлова Т.I, Бойко С.О., Шевченко А.П.Спосіб прогнозування відмов агрегатів суднових комплексів за даними експлуатаційних спостережень. Новітні технології. 2019. Вип.1(8). С.52-58.

4. Будолак С.Ю., Ткаченко В.В., Гуменніков Р.В., Шевченко А.П. Метод структурного синтезу системи управління засобів водного транспорту. 2019. №1(41). C.101-108. DOI: 10.18372/2310-5461.41.13535.

5. Управління технічною експлуатацією флоту : конспект лекцій. URL: http://www.kma.ks.ua/ua/images/2_library/methodical/sud_energ/department/avtomatyka/utef /u1.pdf (дата звернення: 09.12.2018).

6. Основи технічної експлуатації автоматизованої системи управління судном: підручник для студентів вищих навчальних закладів. / Богомья В.І. та ін. ; за ред. О. М. Тимощук. Київ. ДУІТ. 2018. 305 с.

7. Особливості системного підходу до вирішення наукових завдань експлуатації суднового обладнання./ Богомья В.І. та ін. ; за ред. О. М. Тимощук. Київ, ДУІТ, 2018, 305 c.

8. Хайкин С. Нейронные сети: полный курс. Москва: Вильямс, 2006. 1104 с.

9. Седова Н. А., Седова Н. А. Теоретические аспекты нейросетевого управления курсом судна. Транспортное дело России. Москва: Морские вести России, 2006. Спецвыпуск № 7.C. 54- 57.

10. Равин А.А. Диагностическое обеспечение судового энергетического оборудования: проблемы и решения : дис... д-ра техн. наук : 05.08.05. URL: http://docplayer.ru/44925881-Ravin-aleksandr-aleksandrovich-diagnosticheskoe-

obespechenie-sudovogo-energeticheskogo-oborudovaniya-problemy-i-resheniya.html (дата звернення: 30.11.2018). 
11. Разработка метода оценки и прогнозирования технического состояния судовых сложных систем / В. В. Вычужанин та ін. Восточно-Европейский журнал передовых технологий. $2016 . \quad$ №6/9 (84). http://journals.uran.ua/eejet/article/download/85605/87615 (дата звернення: 06.01.2020).

\section{Shevchenko A.P., Plita L.L. ANALYSIS OF METHODS FOR FORECASTING THE TECHNICAL CONDITION OF WATER VEHICLES}

Information on the level of crash-free operation and the efficiency of break passengers and trucks are improving. Special attention is paid to the capture of the specified levels of reliability of technical characteristics. A significant battle in this case - the decision was made to predict the technical age of water transport. This is even more than the actual actual scientific results using the highest efficiency of the technical services of maritime and uniform vehicles, which were submitted for verification of their technical condition.

To date, for the guaranteed reliable reliability of forecasting the technical condition of water transport, the active use of software solutions. The analysis of foreign and domestic experience developed and proposed a systematic forecasting of the technical condition as a composite subsystem, so he proposed water transport in general to provide a significant number of its capabilities for the development of mathematical and algorithmic software. The most relevant in this is the use of models and methods of artificial intelligence, namely, the so-called many calculations.

Key words: model, method, forecasting, technical condition, water transport equipment, artificial intelligence methods, necessary examinations.

\section{Шевченко А.П., Плита Л.Л.}

\section{АНАЛИЗ МЕТОДОВ ПРОГНОЗИРОВАНИЯ ТЕХНИЧЕСКОГО СОСТОЯНИЯ СРЕДСТВ ВОДНОГО ТРАНСПОРТА}

Сведения, уровень безаварийного судинопадиння, работают и эффективность перерыва пассажиров и грузовиков, улучшаются. Специальное внимание уделяется самому захвату заданных уровней надежности технических характеристик. Значительный бой в этом деле - решение решено прогнозировать техническое старость водного транспорта. Это еще больше, чем актуальные фактические научные результаты с использованием наивысшей эффективности технических служб морских и равномерных транспортных средств, поступивших на проверку их технического состояния.

На сегодняшний день для гарантированного достоверного достоверности прогнозирования технического состояния водного транспорта активное использование программного ремения. Анализ зарубежного и отечественного опьта разработан $u$ предложил системную прогнозирования технического состояния как составленного подсистемы, так что он предложил водный транспорт в целом, чтобы обеспечить значительное количество своих возможностей для развития математического $u$ алгоритмического обеспечения. Наиболее актуальным в этом является использование моделей и методов искусственного интеллекта, в частности, так взвешенньх многих вычислений.

Ключевые слова: модель, метод, прогнозирования, техническое состояние, оборудование водного транспорта, методы искусственного интеллекта, необходимые обследования. 